\title{
Fatty acid composition and lipid content in the copepod Limnocalanus macrurus during summer in the southern Bothnian Sea
}

\author{
K. Mäkinen ${ }^{1 *}\left(\mathbb{D}\right.$, M. Elfving ${ }^{1}$, J. Hänninen ${ }^{1}$, L. Laaksonen², M. Rajasilta' ${ }^{1}$ I. Vuorinen ${ }^{1}$ and J.-P. Suomela ${ }^{3}$
}

\begin{abstract}
The lipid reserves and occurrence of the cold-stenothermic, omnivorous copepod Limnocalanus macrurus were studied in the Bothnian Sea (northern Baltic Sea) during spring and summer 2013-2014 with a special emphasis on the fatty acid composition of adults and their potential food. The individual total wax ester (WE) content, determined from the size of oil sacs in the prosoma, ranged on average from 1.3 to $2.6 \mu \mathrm{g}$, and showed a decreasing trend towards September. Lipids were dominated by fatty acids 16:0, 18:1(n-9), 18:2(n-6), 20:5(n-3) and 22:6(n-6), forming 56-61\% of total fatty acids in June-September. Decreasing abundance of adults and reduction of the lipid storage implied that during summer adults suffered from starvation and, as a result, became eliminated from the population. The lipid content and dietary fatty acid markers suggested that in May, adult L. macrurus utilized the phytoplankton bloom, consisting mainly of diatoms and dinoflagellates, but later, during July-September, consumed either algae or heterotrophic organisms sinking from upper water layers or crustaceans inhabiting the same deeper water layers as L. macrurus. In the face of the climate change, the rising temperatures may force L. macrurus permanently to deeper water levels. If also the food resources are limited, we conclude that the summer season may act as a bottleneck limiting the propagation of L. macrurus and having implications further along the food web.
\end{abstract}

Keywords: Zooplankton, Baltic Sea, Lipids, Fatty acids, Wax esters

\section{Background}

Limnocalanus macrurus (Sars 1863) is a cold-stenothermic, omnivorous copepod with a wide distribution in brackish coastal waters and freshwater lakes in the northern America, Europe and Asia [1]. In the Baltic Sea, $L$. macrurus occurs abundantly in low-salinity areas, such as the Bothnian Bay and the Bothnian Sea, where it is one of the most important species of the pelagic ecosystem [2, 3]. The main reproductive period of L. macrurus in the Baltic Sea is in winter and early spring, before the spring phytoplankton bloom [3-6]. As prey organisms are scarce in winter, maturing adults need to collect and store energy during summer in order to be able to reproduce $[7,8]$. Like many high-latitude copepods, $L$.

\footnotetext{
*Correspondence: kamaki@utu.fi

${ }^{1}$ Archipelago Research Institute, Biodiversity Unit, University of Turku, 20014 Turku, Finland

Full list of author information is available at the end of the article
}

macrurus accumulates substantial lipid reserves in the body, which are stored in oil sacs or oil droplets mainly in the form of wax esters (WE) $[8,9]$. These stored lipids have many important functions, serving for example as energy reserves when food availability is low [e.g., 10]. In addition to energy, L. macrurus requires essential fatty acids (EFAs), to ensure growth, survival and successful reproduction [11]. Of these, especially eicosapentaenoic acid (EPA; 20:5(n-3)) and docosahexaenoic acid (DHA; 22:6(n-3)) are crucial [10], as copepods cannot synthesize them $[11,12]$ and have to get them from food. Therefore, the abundant availability of good quality food is important for copepods as the composition of lipids is species- or taxon-specific and, also, dependent on the environmental conditions where they are produced [13].

In the Baltic Sea, the on-going climate change has caused a decline of salinity and a slight increase of water temperature [14]. As L. macrurus mostly lives in cold waters below thermocline [15], the temperature may not 
have affected its abundance this far. Instead, freshening of the water has likely brought about an increase of its biomass in the Bothnian Sea and the Bothnian Bay since 1990 [16]. Projections for the future development of the Baltic Sea suggest a further decline of salinity [17, 18], which may cause species that originate from a high-salinity environment to disappear and freshwater and glacial relict species, such as L. macrurus, to increase in numbers [18]. However, with consequent rising temperatures, the propagation of $L$. macrurus requires that the population is able to reproduce and grow in its distributional areas. More information is needed on the quantity and quality of lipids in L. macrurus and also, on other characteristics relevant to its reproduction and dispersal potential, in order to foresee this development.

In calanoid copepods, visible lipid depositions provide a rapid method for evaluating the nutritional status and energy reserves of an individual $[19,20]$. In L. macrurus, oil sac length has been used for the determination of the lipid content by Vanderploeg et al. [8] in Lake Michigan, and by Dahlgren et al. [6] in the Bothnian Bay. The quality of lipids in L. macrurus is poorly known, as the studies are few and they have mainly focused on populations that live in lakes [21] or in Arctic coastal waters [22, 23]. In the Baltic Sea, the only study investigating the fatty acids of $L$. macrurus gives no information about their seasonal variation but indicates some differences from the lake populations of the same latitude [21].

In the present study, we examine the lipid content and fatty acid composition of adult L. macrurus in the southern part of the Bothnian Sea $\left(60^{\circ} 42^{\prime} 14.6^{\prime \prime} \mathrm{N}\right.$ $20^{\circ} 41^{\prime} 3.04^{\prime \prime} \mathrm{E}$ ), in an area, characterized by uneven bottom topography and a water depth ranging between 20 and $60 \mathrm{~m}$. Due to an isolating effect of the Archipelago Sea in the south and direct river runoff from the Finnish coast, the impact of freshwater is strong in the area. Due to this, halocline is weak and water stratification is mainly controlled by temperature variations [24]. The two-year study was carried out during the main production period of the plankton community [25], which is also the main feeding period of L. macrurus in this sea area. Following the studies by Vanderploeg et al. [8] and Dahlgren et al. [6], we used oil sac length as a proxy for lipid content. Fatty acids were determined over summer from adult L. macrurus and plankton samples, composed of a mixture of phytoplankton and zooplankton species, in order to study if the trophic relationships between $L$. macrurus and its food could be detected using fatty acid trophic markers [26]. We also examined the vertical distribution of L. macrurus, as the feeding conditions are likely to differ by depth and, therefore, affect its lipid reserves, abundance, and reproduction.

\section{Methods}

Hydrological and plankton sampling

Limnocalanus macrurus was collected for fatty acid analyses on May 23, June 12, July 1 and September 9, 2013 (Table 1). Several vertical hauls were taken from the bottom (50 $\mathrm{m}$ depth) to the sea surface using a $150-\mu \mathrm{m}$ standard plankton net $(\varnothing 35 \mathrm{~cm})$. The contents of the net were emptied to 3 - L glass vials, which were filled with sea water and covered with a perforated aluminium foil to ensure aeration. The vials were transported to a laboratory in insulated containers, having some ice to keep the

Table 1 Sampling dates, sampling depth $(\mathrm{m})$ and methods used in collecting Limnocalanus macrurus (LM; ind./m ${ }^{3}$ ) and mixed plankton samples $\left(P L ;\right.$ ind./ $\mathrm{m}^{3}$ ) from the Bothnian Sea for different analyses

\begin{tabular}{|c|c|c|c|c|c|}
\hline Season & Date & Variable & Depth (m) & Method used & Analyses \\
\hline \multirow[t]{2}{*}{ Spring } & May 23, 2013 & LM & $0-50$ & $\mathrm{SN}(150 \mu \mathrm{m})$ & $F A(n=3), A(n=1)$ \\
\hline & & $P L$ & $0-10$ & $\mathrm{SN}(50 \mu \mathrm{m})$ & FA (pooled) \\
\hline \multirow[t]{2}{*}{ Summer } & June 12, 2013 & LM & $0-50$ & SN $(150 \mu \mathrm{m})$ & $\mathrm{FA}(\mathrm{n}=1)$ \\
\hline & & $P L$ & $0-10$ & $\mathrm{SN}(50 \mu \mathrm{m})$ & FA (pooled) \\
\hline \multirow[t]{2}{*}{ Summer } & July 1, 2013 & LM & $0-50$ & $\mathrm{SN}(150 \mu \mathrm{m})$ & $F A(n=3), A(n=1)$ \\
\hline & & $P L$ & $0-10$ & $\mathrm{SN}(50 \mu \mathrm{m})$ & FA (pooled) \\
\hline \multirow[t]{2}{*}{ Summer } & Sept 9, 2013 & LM & $0-50$ & $\mathrm{SN}(150 \mu \mathrm{m})$ & $F A(n=3), A(n=1)$ \\
\hline & & $\mathrm{PL}$ & $0-10$ & SN $(50 \mu \mathrm{m})$ & FA (pooled) \\
\hline Spring & May 20, 2014 & LM & $0-25,25-50$ & 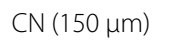 & $A, \operatorname{Vd}(n=3)$ \\
\hline Summer & July 1, 2014 & LM & $0-25,25-50$ & CN $(150 \mu \mathrm{m})$ & $A, \operatorname{Vd}(n=3)$ \\
\hline Summer & July 22, 2014 & LM & $0-25,25-50$ & CN $(150 \mu \mathrm{m})$ & $A, \operatorname{Vd}(n=3)$ \\
\hline Summer & Aug 15, 2014 & LM & $0-25,25-50$ & CN $(150 \mu \mathrm{m})$ & $A, V d(n=3)$ \\
\hline Summer & Sept 16, 2014 & LM & $0-25,25-50$ & 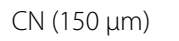 & $A, \operatorname{Vd}(n=3)$ \\
\hline
\end{tabular}

See text for further explanations

FA fatty acid analysis, $A$ abundance, $V d$ vertical distribution, $n$ number of samples, $S N$ standard net, $C N$ closing net 
temperature low. In the laboratory, the plankton material was poured through a 2-mm plankton sieve and gently washed to a Petri dish, where the organisms were lightly anesthetized with carbon dioxide to facilitate sorting. Living adult L. macrurus were picked individually into 4-mL cryogenic glass tubes, which were filled with 3-4 mL of chloroform: methanol $(2: 1 ; \mathrm{v} / \mathrm{v})$ and sealed with a Teflon cap to prevent lipid oxidation. At each sampling date, with the exception of June 12, 3 replicate samples were collected, each containing 30-32 individuals. On June 12, we were able to obtain only one sample with 30 individuals due to rough weather conditions. After collection, the samples were stored at $-80{ }^{\circ} \mathrm{C}$ until the fatty acid analysis.

Concurrently with the L. macrurus samples, profiles of salinity (PSU) and temperature $\left({ }^{\circ} \mathrm{C}\right)$ were taken with a CTD-probe at the depth of $0-50 \mathrm{~m}$. Also, plankton (referred as "mixed plankton") was sampled in order to compare the fatty acid compositions between $L$. macrurus and its potential prey. At each sampling date, a $50-\mu \mathrm{m}$ standard plankton net was horizontally hauled at variable depths $(0-10 \mathrm{~m})$ until a sufficient amount of material was obtained (Table 1 ). The hauling speed was $2-3$ knots. The samples were treated in a similar way as that of $L$. macrurus, except that in the laboratory, the plankton mass was sieved through a $50-\mu \mathrm{m}$ plankton net to remove excess water. After that, the plankton mass was moved to an aluminium foil, freeze-dried and stored at $-80{ }^{\circ} \mathrm{C}$ until the fatty acid analysis. In order to determine the species composition and their relative abundance, the samples were gently mixed before freeze-drying and a $2-3-\mathrm{mL}$ random sample was taken from the mixture and preserved in $4 \%$ buffered formalin. The preserved samples were then analyzed under an inverted microscope and determined to species or genus level, whenever possible. The relative abundance of different taxonomic groups was estimated as $(+++)=$ highly abundant, $(++)=$ abundant and $(+)=$ present in low numbers.

In order to estimate the abundance of L. macrurus, mesozooplankton samples were collected in 2013 and 2014 (Table 1). In 2013, one vertical haul was taken from the bottom (50 m depth) to the surface with the $150-\mu \mathrm{m}$ standard plankton net. In 2014, three replicate samples were collected in a similar manner but with a $150-\mu \mathrm{m}$ closing plankton net $(\varnothing 30 \mathrm{~cm})$ from two water layers $(0-25$ and $25-50 \mathrm{~m})$ separately, in order to also study the vertical distribution of $L$. macrurus. All samples were preserved in buffered $4 \%$ formalin and examined under an inverted microscope. The number of L. macrurus in the samples was counted using three identification categories (adults, copepodites, and nauplii) and abundance was expressed as number of individuals per $\mathrm{m}^{3}$.

\section{Somatic measurements}

Total body (BL; without antenna and setae of the furca), prosome and oil sac lengths were measured in 2013-2014 from a sample of 15-55 adult $L$. macrurus/date using an inverted microscope and an ocular micrometer (precision $25 \mu \mathrm{m}$ ). During measuring, the presence of spermatophores in adult females was recorded as an indicator of reproduction. Following Dahlgren et al. [6] and Vanderploeg et al. [8], oil sac length in adult $L$. macrurus was measured from oil sacs found in the prosome region and used as a proxy for the lipid mass. The oil sac length was measured from the anterior edge to the posterior edge of an oil sac. The measured lengths were summed if multiple oil sacs were present. Similarly to Vanderploeg et al. [8] and Dahlgren et al. [6], oil sacs were assumed to consist mainly of WE and calculated as total WE content ( $\mu \mathrm{g} /$ ind.) and concentration (WE \% of dry weight) in order to make comparisons with different studies. The WE concentration was calculated by first converting the prosome length to carbon biomass $(\mathrm{CB})$ using a length-CB regression $\left(r^{2}=0.41\right)$, given by Kankaala and Johansson [27], and then converting it to dry weight (DW) assuming that DW is 2.5 times the CB [28]. The oil sac length was converted to total WE content according to the regression proposed by Vanderploeg et al. [8]: $y=\exp (3.07 x)$, where $y$ is WE $(\mu \mathrm{g})$ and $x$ is the oil sac length $(\mathrm{mm})$.

\section{Fatty acid analyses}

Lipids were extracted from samples of L. macrurus ( $\mathrm{n}=1-3 /$ sampling date) and mixed plankton (pooled sample) by a modified Folch method using chloroform/ methanol $(2: 1, \mathrm{v} / \mathrm{v})$ [29]. Each sample of $L$. macrurus, containing 30-32 adults, and mixed plankton, containing 5-20 mg of plankton mass, were homogenized and the chloroform-methanol solution was poured into a glass tube where an internal standard (triheptadecanoin; Larodan Fine Chemicals AB, Malmö, Sweden) and 200$\mu \mathrm{L}$ amount of $0.88 \%$ potassium chloride solution (Merck KGaA, Darmstadt, Germany) had been added. Nitrogen was then added to the tubes to prevent fat oxidation, after which tubes were capped and shaken at $460 \mathrm{U} / \mathrm{min}$ for $1 \mathrm{~h}$. After that, $0.88 \%$ potassium chloride was again added to the tubes so that the proportion of chloroform, methanol and potassium chloride solution was 8:4:3 (by vol.). The samples were mixed and the lower phase in each sample was collected into a tared glass vial, evaporated to dryness and weighed. The samples were dissolved in $1 \mathrm{~mL}$ of chloroform and stored at $-80{ }^{\circ} \mathrm{C}$ until the preparation of fatty acid methyl esters (FAME).

FAME were prepared in $92{ }^{\circ} \mathrm{C}$ by boron trifluoride ( $10 \%$ in methanol, p.a.; Fluka, Buchs, Switzerland), which catalyzed transesterification from the lipid extracts after the solvent was evaporated under nitrogen [30, 31]. 
FAME (dissolved in hexane) were analyzed by gas chromatography with flame ionization detection (GC-FID) (PerkinElmer AutoSystem, Norwalk, CT) by using a DB-23 column $(60 \mathrm{~m} \times 0.25 \mathrm{~mm}$ i.d., $0.25 \mu \mathrm{m}$ film thickness; Agilent Technologies, Palo Alto, CA) and identified with help of 68D FAME mixture (Nu-Chek-Prep, Inc.). This approach enabled identification of fatty acids in all samples, with the exception of those of L. macrurus, collected in May, where exceptional peak characteristics were observed in the chromatograms. Therefore, the samples of L. macrurus were further analysed using gas chromatography-mass spectrometry (GC-MS), which showed overlapping peaks of fatty acids 16:1(n-7), 20:0, 20:2(n-6) and 22:1(n-9) with a homologous series of saturated hydrocarbons, having 22-28 carbon atoms. Because of this, the exact quantity of these fatty acids could not be determined from the May samples of $L$. macrurus. Conversely, for the samples that were collected in June-September, a percentage composition of fatty acids (FA weight percentage (\%) of total fatty acids) was calculated on the basis of their gas chromatographic peak areas. The fatty acids of $L$. macrurus were also expressed as concentration per adult ( $\mu \mathrm{g} / \mathrm{ind}$.), when appropriate.

\section{Statistical analyses}

All statistical analyses were done with $\mathrm{R}$ statistical software version 3.2.0 [32]. One-way analyses of variance (ANOVA) were used to detect differences in $\log 10(\mathrm{x}+1)$-transformed abundance (ind. $\left./ \mathrm{m}^{3}\right)$ of $L$. macrurus among sampling dates and depths $(0-25 \mathrm{~m}$ and 25-50 $\mathrm{m}$ depth). Also, differences in the total body length $(\mu \mathrm{m})$, total WE content $(\mu \mathrm{g} / \mathrm{ind}$.) and proportion of WE (\% DW) were tested between sampling years and dates using the ANOVA. Monthly variation of selected fatty acids in L. macrurus ( $\mu$ g/ind.) (18:1(n-9), EPA and DHA) was also tested in a similar manner. In addition, Pearson correlation was used to study the correlation between the oil sac and body and prosome lengths.
Principal component analysis (PCA) was used to compare the fatty acid composition of $L$. macrurus and mixed plankton, and to identify those fatty acids that accounted for most of the variation of fatty acids between them. All fatty acids from June 12, July 1 and September 9, 2013, were included in the analysis. PCA was carried out with the VEGAN package 2.2-1 in $\mathrm{R}$ [33]. In particular, the function prcomp was used because it uses singular value decomposition (SVD) technique that allows computation of PCA even in cases when there are as many, or more variables than there are samples [34]. Prior to their inclusion to the PCA, the data (\% of total FAs) was standardized to a mean of zero and unit variance. Sample scores extracted from principal component 1 (PC1) and 2 (PC2) were compared between $L$. macrurus and mixed plankton using one-way ANOVA.

\section{Results}

Salinity and temperature

During the study period, the temperature ranged between 2 and $18{ }^{\circ} \mathrm{C}$. In 2013, depending on the month, the water temperatures were on average $2-5{ }^{\circ} \mathrm{C}$ lower than in 2014 (Table 2). In both years, thermocline developed approximately at 10-20 m depth after May. Salinity varied between 4 and 7 and halocline was very weak or absent. No large differences were observed among salinity levels in 2013 and 2014 (Table 2).

\section{Abundance, vertical distribution and WE content of $L$. macrurus}

In May-June, adult stages of L. macrurus were present in high abundances, but their abundance decreased towards July-September (Fig. 1). The samples, collected from two depth layers in 2014, showed that adults had a clear preference for deep water (Fig. 1). In May, adults were found in the whole water column, but in higher abundances below $25 \mathrm{~m}$ than above it. Conversely, in the beginning of July, adults had almost vanished from the upper water layer and occurred mostly in deep water (Fig. 1). This observation

Table 2 Temperature $\left(\mathrm{T} ;{ }^{\circ} \mathrm{C}\right.$ ) and salinity (S; PSU) at 0-25 $\mathrm{m}$ and 25-50 $\mathrm{m}$ depth in the southern Bothnian Sea during samplings in May-September 2013 and 2014

\begin{tabular}{|c|c|c|c|c|c|c|c|c|c|}
\hline \multirow[t]{2}{*}{ Depth (m) } & \multicolumn{4}{|l|}{2013} & \multicolumn{5}{|l|}{2014} \\
\hline & May 23 & June 12 & July 1 & Sept 1 & May 20 & July 1 & July 22 & Aug 15 & Sept 16 \\
\hline \multicolumn{10}{|l|}{$\mathrm{T}$} \\
\hline $0-25$ & 5.7 (1.9) & $15.0(3.2)$ & $15.0(3.2)$ & $15.0(3.2)$ & - & $10.7(1.2)$ & $14.7(5.1)$ & $18.2(3.9)$ & $14.2(2.4)$ \\
\hline $25-50$ & $2.5(0.4)$ & $4.1(0.4)$ & $4.1(0.4)$ & $4.1(0.4)$ & - & $6.0(1.5)$ & $5.9(0.9)$ & $7.3(0.4)$ & $5.5(0.7)$ \\
\hline \multicolumn{10}{|l|}{ S } \\
\hline $0-25$ & $5.0(1.4)$ & $5.1(1.4)$ & $5.5(0.1)$ & $5.5(0.0)$ & - & $5.7(0.1)$ & $5.5(0.3)$ & $4.6(1.7)$ & $5.4(0.1)$ \\
\hline $25-50$ & $5.6(0.1)$ & $5.8(0.1)$ & $5.5(0.0)$ & $5.8(0.1)$ & - & $5.7(0.1)$ & $5.7(0.1)$ & $6.6(0.2)$ & $5.7(0.1)$ \\
\hline
\end{tabular}

Mean and \pm SD (in parenthesis) are shown; $(-)=$ no data obtained 


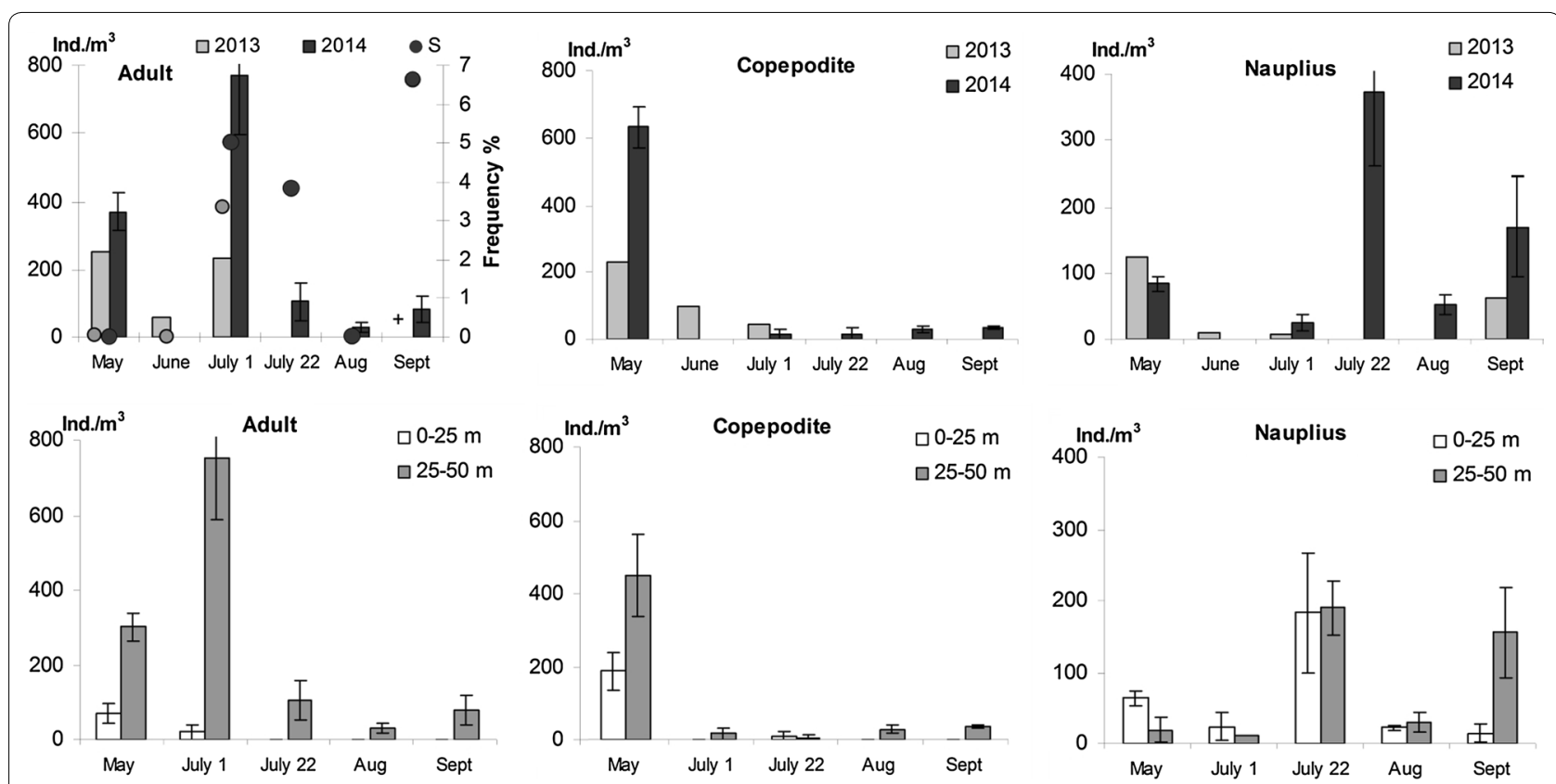

Fig. 1 Abundance (mean $\pm S D$ ind./ $\mathrm{m}^{3}$ ) of Limnocalanus macrurus adults, copepodites, and nauplii in the southern Bothnian Sea. Upper pannels indicate abundance at 0-50 m depth in May-September 2013 and 2014. Lower panels indicates the abundance at different water layers in May-September 2014. S = the prevalence of spermatophores attached to the females in May-September 2013 and 2014 (frequency; \% of females examined); grey circle $=2013$; black circle $=2014 ;(+)=<1 \mathrm{ind} . / \mathrm{m}^{3}$. Note different scales of $\mathrm{y}$-axis

was supported by one-way ANOVA, yielding a significant difference in the abundance of adults between months when analyzed separately for both water layers $(0-25 \mathrm{~m}$ : $\mathrm{F}(4,10)=12.47, p<0.001 ; 25-50 \mathrm{~m}: \mathrm{F}(4,11)=32.91$, $p<0.001)$. The abundance also differed between the two depth layers $(\mathrm{F}(1,28)=10.25, p=0.003)$. Adult females carried spermatophores in July and September, with a frequency of $3-6 \%$ (number of females examined $=183$ ), whereas no spermatophores were found in May and August (Fig. 1). In both study years, copepodites were found abundantly only in May, and like adults, they were more numerous in deep water than in the surface layer (Fig. 1). The abundance of nauplius-stages varied during summer, as shown in 2014 when sampling was more frequent than in 2013. A clear peak in the abundance of nauplii was observed on July 22 and another one in September, when they were found mainly in the deeper water layer (Fig. 1).

The mean body length (BL) of adult $L$. macrurus differed between the years $(\mathrm{F}(1,156)=16.44, p<0.001)$. BL also varied among months in both years $(2013: \mathrm{F}(2,38)=8.01$, $p<0.001 ; 2014: \mathrm{F}(3,113)=10.26, p<0.001)$. In 2014, the largest adults were found in May, while in 2013, the largest values were found in the beginning of July (Fig. 2a). Throughout the study period, BL was highly correlated with the prosome length $(\mathrm{r}=0.98 ; p<0.001 ; \mathrm{df}=156)$. In May 2013 and 2014, all adults had either large or medium-sized oil sacs in their prosome, but the frequency of individuals, having no oil sacs greatly increased during summer in both study years (Fig. 2a). The oil sac length also varied substantially among adults. Correlation between the oil sac and prosome length was positive and significant only in May and September 2014 (May: $\mathrm{r}=0.56 ; p<0.001$, $\mathrm{df}=44$; September: $\mathrm{r}=0.43, p=0.01, \mathrm{df}=32$ ). Consequently, the between-individual variation was high also in the estimates of total content (WE $\mu \mathrm{g} / \mathrm{ind}$.) and concentration of WE (WE \% DW). These values showed no differences between the years $(\mathrm{F}(1,194)=0.48, p=0.49 ; \mathrm{F}(1$, $194)=0.01, p=0.91$, respectively) (Fig. 2b). The total WE content ( $\mu \mathrm{g} /$ ind.) and WE concentration (WE \% DW) differed significantly by months in $2014(\mathrm{~F}(3,148)=15.53$, $p<0.001 ; \mathrm{F}(3,148)=15.40, p<0.001$, respectively), when samples were obtained from May to September, but not in 2013, when the sampling period was shorter (Fig. 2b). Both the total WE content and WE concentration were lower May 2013 than in 2014, but in the beginning of July showed equal amounts in both years (Fig. 2b). From July 2014, the WE content and concentration remained rather constant until September with the exception of June 22 when the values were much higher than in other dates (Fig. 2b).

\section{Relative fatty acid proportions in L. macrurus and mixed plankton}

The fatty acid composition of $L$. macrurus showed a high diversity in the number of single fatty acids, but 

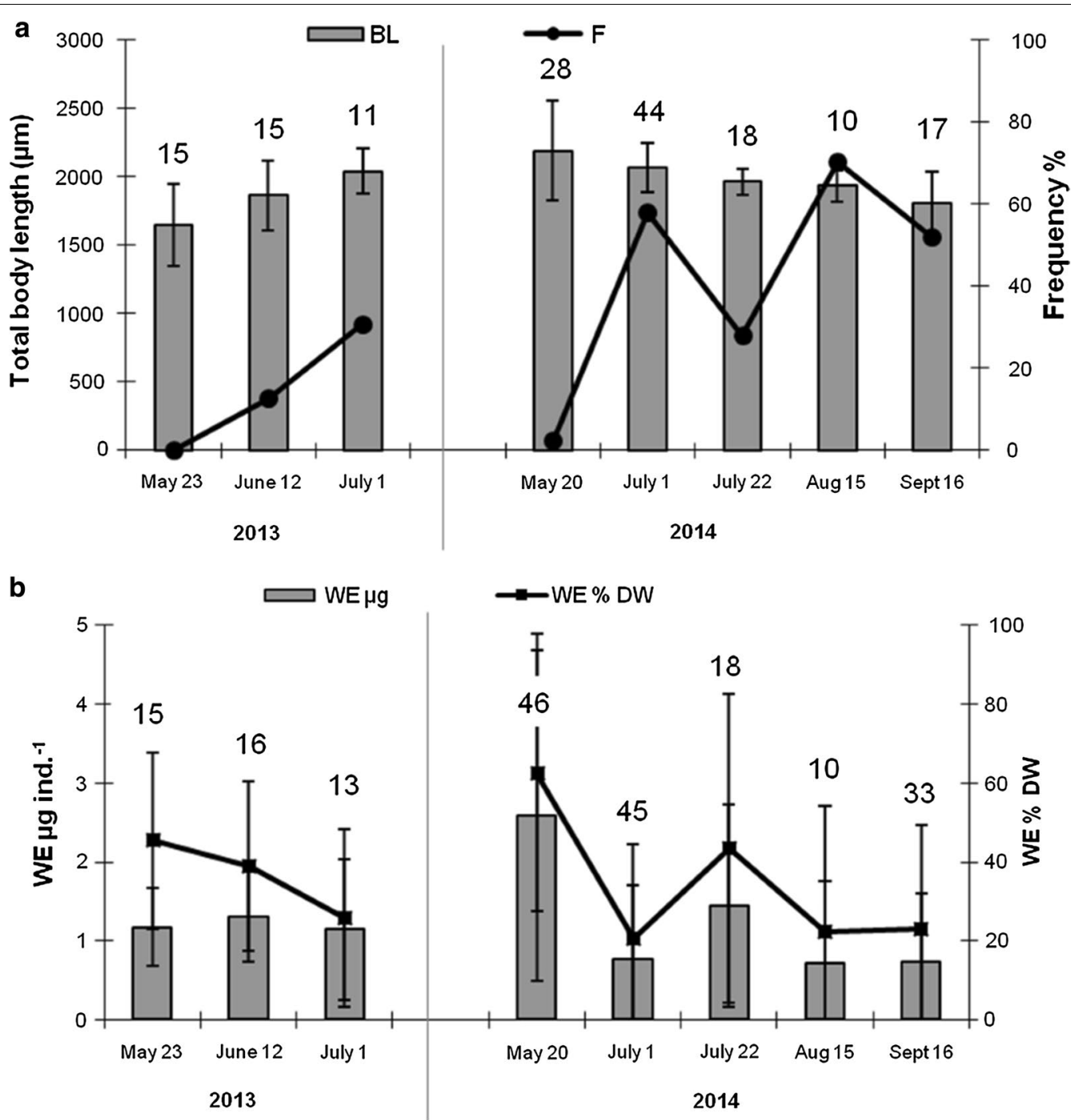

Fig. 2 a Total body length (BL; mean $\pm S D \mu m$ ) of adult Limnocalanus macrurus and frequency ( $F$ \%) of adults with no oil sacs, b concentration (WE $\mu \mathrm{g} /$ ind.; mean \pm SD) and percentage (WE \% DW; mean \pm SD) of wax esters in adult L. macrurus at different dates in 2013 and 2014 in the southern Bothnian Sea. Total number of individuals examined each year is shown at the top of the columns

as majority of them were identifiable only as traces or they had a very low proportion of the total FAs $(<0.5 \%)$, they were expressed as a pooled group called "Others" (Table 3). This group seemed to include several saturated fatty acids (e.g., 11:0, 12:0, 15:0, 19:0, 21:0, 22:0, 23:0, 24:0), but also traces of polyunsaturated fatty acids, such as arachidonic acid (20:4(n-6)), were found. In June-September, lipids were dominated by a high proportion of 16:0, 18:1(n-9), 18:2(n-6), EPA and DHA (Table 3). Of the polyunsaturated FAs, EPA had a maximum value in June and a low value in September, while DHA in turn, showed an opposite trend with a low proportion in June and a higher proportion in July and September (Table 3).
The samples of mixed plankton were composed of a large variety of plankton organisms typical of the season (Table 4). Cyanobacteria were present in all samples, while diatoms and dinoflagellates had the highest relative abundance in May. Rotatorians, cladocerans and adult copepods were abundant in the samples mainly in June and July, while copepod nauplii and copepodites were found in all months. In September, the samples contained a high number of the ciliate Helicostomella subulata, but also dinoflagellates and Acartia spp. nauplii were present (Table 4). The fatty acid composition of mixed plankton was dominated by $14: 0,16: 0,16: 1(n-7)$ and EPA, each having a relative proportion of $>10 \%$ of the total FAs (Table 4). The proportion of fatty acids showed 
Table 3 Relative proportions of major fatty acids (\% of total FAs; mean \pm SD) in adult Limnocalanus macrurus and mixed plankton during summer 2013 in the southern Bothnian Sea

\begin{tabular}{|c|c|c|c|c|c|c|c|}
\hline \multirow[t]{2}{*}{ Fatty acid } & \multicolumn{3}{|c|}{ L. macrurus } & \multicolumn{4}{|c|}{ Mixed plankton } \\
\hline & $\begin{array}{l}\text { June } 12 \\
(n=1)\end{array}$ & $\begin{array}{l}\text { July } 1 \\
(n=3) \\
\text { mean } \pm \text { SD }\end{array}$ & $\begin{array}{l}\text { Sept } 9 \\
(n=3) \\
\text { mean } \pm \text { SD }\end{array}$ & $\begin{array}{l}\text { May } 23 \\
\text { (P) }\end{array}$ & $\begin{array}{l}\text { June } 12 \\
\text { (P) }\end{array}$ & $\begin{array}{l}\text { July } 1 \\
\text { (P) }\end{array}$ & $\begin{array}{l}\text { Sept } 9 \\
\text { (P) }\end{array}$ \\
\hline $14: 0$ & 2.7 & $2.0 \pm 0.5$ & $1.5 \pm 0.6$ & 11.6 & 8.6 & 8.3 & 7.9 \\
\hline $16: 0$ & 9.0 & $10.7 \pm 1.0$ & $8.7 \pm 1.4$ & 17.0 & 20.7 & 25.1 & 20.0 \\
\hline $18: 0$ & 2.9 & $3.6 \pm 0.5$ & $2.4 \pm 0.6$ & 0.7 & 4.4 & 6.1 & 3.3 \\
\hline $20: 0$ & 0.8 & + & + & 4.1 & 0.9 & 3.5 & 5.2 \\
\hline $16: 1(n-7)$ & 1.1 & $1.2 \pm 0.5$ & $1.6 \pm 0.1$ & 22.9 & 7.5 & 5.4 & 6.7 \\
\hline $18: 1(n-7)$ & 1.0 & $1.5 \pm 0.4$ & $1.8 \pm 1.4$ & - & 1.1 & 1.7 & 2.3 \\
\hline $18: 1(n-9)$ & 6.3 & $9.7 \pm 3.0$ & $15.6 \pm 2.1$ & 8.0 & 6.7 & 5.8 & 5.0 \\
\hline $20: 1(n-9)$ & - & + & + & 5.2 & 0.9 & - & 0.9 \\
\hline $22: 1(n-9)$ & 0.8 & $2.3 \pm 2.0$ & $0.8 \pm 0.2$ & 0.7 & 1.8 & 2.4 & 0.5 \\
\hline $24: 1(n-9)$ & 1.3 & $0.8 \pm 0.0$ & $1.0 \pm 0.0$ & + & + & + & + \\
\hline $20: 2(n-6)$ & 1.4 & $1.8 \pm 0.9$ & $3.3 \pm 0.8$ & - & + & - & - \\
\hline $20: 3(n-3)$ & 1.0 & $1.6 \pm 0.6$ & $2.8 \pm 0.6$ & - & + & - & - \\
\hline $18: 2(n-6)$ & 8.3 & $9.4 \pm 2.3$ & $10.5 \pm 0.8$ & 1.7 & 4.5 & 4.2 & 2.7 \\
\hline $18: 3(n-3)$ & 4.3 & $4.5 \pm 0.7$ & $4.6 \pm 0.2$ & 1.5 & 6.7 & 6.2 & 6.8 \\
\hline $18: 4(n-3)$ & 3.9 & $3.9 \pm 0.4$ & $3.5 \pm 0.6$ & - & - & - & - \\
\hline $20: 5(n-3)$ & 22.9 & $11.2 \pm 0.6$ & $10.1 \pm 0.9$ & 12.1 & 11.2 & 12.6 & 15.7 \\
\hline $22: 6(n-3)$ & 9.9 & $18.3 \pm 1.1$ & $16.1 \pm 1.4$ & 8.6 & 15.2 & 13.9 & 13.2 \\
\hline Others & 22.4 & $17.8 \pm 6.2$ & $15.4 \pm 0.3$ & 5.9 & 9.8 & 4.8 & 9.8 \\
\hline Total & 100.0 & 100.0 & 100.0 & 100.0 & 100.0 & 100.0 & 100.0 \\
\hline
\end{tabular}

$\mathrm{n}=$ number of samples (containing 30-32 ind./sample); $\mathrm{P}=$ pooled sample; $(-)=$ not detected; $(+)$ proportion $<0.5 \%$; included in the group "Others"

relatively little variation among months, with the exception of 16:1(n-7), which was the dominant fatty acid in May, but later in summer, decreased to clearly lower levels (Table 3).

The PCA analysis separated the samples of $L$. macrurus from those of mixed plankton (Fig. 3). The first two principal components (PC) explained $74 \%$ of the variance extracted by the PCA (weight percentage (\%) of total FAs) (PC1-60\% and PC2-14\%). The sample scores extracted for PC1 were significantly different $(\mathrm{F}(1,8)=171.06$, $p<0.001)$, whereas the sample scores for PC2 were not $(p=0.7)$. According to the loadings of PC1, the separation was caused by high proportions of 14:0, 16:0 and $16: 1(\mathrm{n}-7)$ in the mixed plankton samples (high positive loadings) and high proportions of 18:2(n-6), 18:4(n-3), 20:3(n-3) and 24:1(n-9) (high negative loadings) in the $L$. macrurus samples.

\section{Fatty acid content of $L$. macrurus}

In June-September, an adult L. macrurus contained on average 3-6 $\mu \mathrm{g}$ fatty acids per individual. The content of most single fatty acids did not vary seasonally and only a few fatty acids suggested patterns during the study period. One of these was DHA, which increased from $0.33 \pm 0.08 \mu \mathrm{g} /$ ind. in May to $0.79 \pm 0.08 \mu \mathrm{g} /$ ind. in September (one-way ANOVA; $\mathrm{F}(3,6)=7.73$, $p=0.02)$. Also, 18:1(n-9) and EPA varied among months $(\mathrm{F}(3,6)=7.04, p=0.02 ; \mathrm{F}(3,6)=30.07, p<0.001$, respectively). EPA showed its highest values in June $(1.14 \mu \mathrm{g} /$ ind.) and 18:1(n-9) increased from lower levels in MayJuly $(0.16-0.32 \mu \mathrm{g} / \mathrm{ind}$.) to higher ones in September $(0.79 \pm 0.23 \mu \mathrm{g} /$ ind. $)$.

\section{Discussion}

The reproductive cycle of $L$. macrurus has been described by Kankaala [5] and Lindqvist [3] in the Bothnian Sea and by Dahlgren et al. [6] in the Bothnian Bay. According to Lindqvist [3], males and females copulate during the winter months; nauplii hatch before or during the spring phytoplankton bloom and develop into copepodites and adults in late spring and early summer. The studies outline the reproductive cycle of the species only broadly, but it is considered univoltine like in some lakes [e.g., 7, 35], with minor reproduction in other seasons than in spring. In the present study, sampling was started in May when the naupliar phase was mostly over and the majority of the generation born earlier in spring had developed into copepodites and adults. By the beginning of 
Table 4 Major taxonomic groups identified from plankton samples ("mixed plankton") used in fatty acid analyses in 2013

\begin{tabular}{|c|c|c|c|c|}
\hline \multirow[t]{2}{*}{ Taxonomic group } & \multicolumn{4}{|l|}{ Date } \\
\hline & May 23 & June 12 & July 1 & Sept 9 \\
\hline Aphanizomenon flos-aquae & + & ++ & + & ++ \\
\hline Nodularia spumigena & & & + & + \\
\hline Anabaena sp. & & & + & \\
\hline Gonyaulax spp. & +++ & + & & + \\
\hline Dinophysis spp. & +++ & + & + & ++ \\
\hline Peridinium spp. & + & & & \\
\hline Chaetoceros wighamii & ++ & & & + \\
\hline Achnanthes taeniata & + & & & + \\
\hline Thalassiosira baltica & + & & + & + \\
\hline Helicostomella subulata & & & + & +++ \\
\hline Tintinnopsis lobiancoi & + & + & + & + \\
\hline Keratella quadrata & & + & ++ & + \\
\hline K. cruciformis & & + & & + \\
\hline Synchaeta baltica & + & ++ & +++ & \\
\hline S. monopus & & +++ & & \\
\hline S. curvata & & ++ & & \\
\hline Pleopsis polyphemoides & & & ++ & + \\
\hline Bosmina coregoni & & & ++ & \\
\hline Evadne nordmanni & & + & ++ & + \\
\hline Acartia spp. n. & + & + & & ++ \\
\hline Acartia spp. cop. & + & & & + \\
\hline Acartia spp. ad. & & ++ & ++ & + \\
\hline Eurytemora sp. n. & + & & + & + \\
\hline Eurytemora sp. cop. & & & + & \\
\hline Eurytemora sp. ad. & + & ++ & + & + \\
\hline Temora longicornis $n$. & & & ++ & \\
\hline T. longicornis ad. & & & + & \\
\hline Limnocalanus macrurus $n$. & & + & & + \\
\hline Polychaeta larvae & & & + & \\
\hline Lamellibranciata larvae & & & + & \\
\hline
\end{tabular}

Relative abundance is expressed as follows: $(+++)=$ highly abundant; $(++)=$ abundant $;(+)=$ present in low numbers

n. nauplius, cop. copepodite, ad. adult

July, practically all copepodites had become adults. The presence of spermatophores, although only in $3-6 \%$ of the females, suggested that part of the spring generation attained sexual maturity and reproduced during July. As a consequence, the abundance of nauplii clearly increased at the end of July, although their abundance can be considered only indicative due to the used sampling net, which catches mainly the largest naupliar phases. Nevertheless, the observed peak did not result in an increase of copepodites as can be expected.

In May-July, the abundance of adult L. macrurus was $200-770$ ind. $/ \mathrm{m}^{3}$, which is higher than that in the Bothnian Bay in the same months $\left(200-300\right.$ ind. $\left./ \mathrm{m}^{3}\right)$ [6].

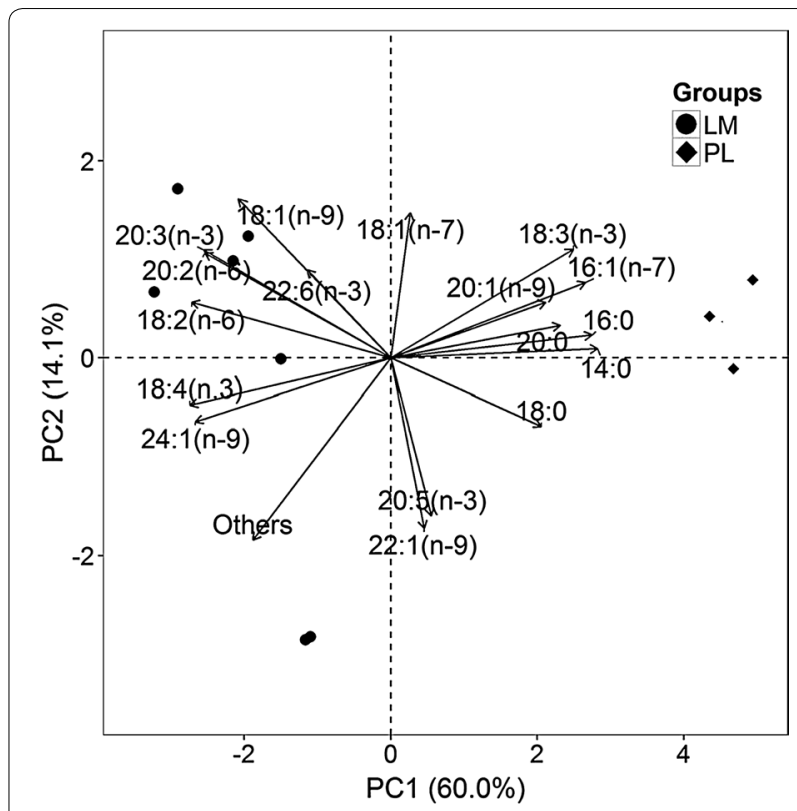

Fig. 3 PCA Biplot of fatty acid proportions (\% of total fatty acids) of Limnocalanus macrurus (LM) (number of samples; $n=7$ ) and mixed plankton (PL) $(n=3)$, collected in the southern Bothnian Sea in June 12, July 1 and September 9 2013. Prior to the PCA, data was standardised to a mean of zero and unit variance

However, by the end of July, the population of adults decreased strongly, for an unknown reason. In May, adults were rather dispersed in the water column but descended to deep water when the water temperature at sea surface started to rise. For a cold-stenothermic species, moving down to lower temperatures is understandable but could also be influenced by the presence of planktivores such as the Baltic herring (Clupea harengus membras), which in the Bothnian Sea preys heavily on adult L. macrurus during May and June [36]. In order to avoid the visually foraging fish, adults move from surface to deep water, but as a trade-off, they may suffer from a scarcity of food because their prey organisms occur at higher abundances closer to the surface [37, 38].

Like many other species of the copepod genera, $L$. macrurus stores lipids mainly in the form of WE in large oil sacs or oil droplets in the body, which enables them to survive long periods of starvation and to provide energy for reproduction [10]. In the current study, the WE content of $L$. macrurus in May-September was on average $1.3-2.6 \mu \mathrm{g} /$ ind., which is more than what is reported for Pseudocalanus acuspes $(0.9-1.8 \mu \mathrm{g} / \mathrm{ind})$ [39], the preferred prey species of the Baltic herring in the Central Baltic Sea [40]. In spite of these apparently large energy reserves, the frequency of oil sacs and WE content varied between months as well as among individuals, collected on the same day, implying that food 
resources were not equally partitioned within the population. In both study years, all adults examined had oil sacs in their body in May, suggesting that there was enough food in the environment to be collected and stored for later use. However, from May onwards, the frequency of individuals with no oil sacs increased, and by the end of the summer, $50-70 \%$ of the adults had no energy reserves at all. To a degree, the reduction of the energy reserves could be a result of reproduction processes such as egg production, requiring a great deal of energy and materials [10]. However, the low proportion of females with spermatophores versus the high proportion of adults with no energy reserves suggests that the reduction was largely caused by factors other than reproduction. The parallel trends between the abundance of adults and the frequency of oil sacs among them suggests that adults suffered from starvation and, as a result, became eliminated from the population. This idea of high mortality due to starvation is supported by Webster et al. [37], who suggested that high predation pressure and increasing temperature at sea surface force adults downwards, with the result that the population concentrates in a smaller space where competition for food resources increases. If only a part of the adults survives and reproduce in these conditions, the summer season could, therefore, act as a bottleneck for the population growth of L. macrurus, despite it is the main production period of its food resources [25]. High mortality due to starvation could also explain the low abundance of copepodites in late summer, but this is not known as their nutritional status was not examined.

It is possible that some oil sacs remained undetected in microscopic scrutiny due to their small size, poor visibility or awkward position within the carapax. Therefore, the size of oil deposits is not necessarily an exact measure of the energy reserves and could explain part of the between-individual variation in the content and concentration of WE. Nevertheless, the average values of WE content in our study agree well with those reported previously by Dahlgren et al. [6] from the Bothnian Bay in the same season (1.7-2.2 $\mu \mathrm{g} / \mathrm{ind}$.). The concentration of WE, instead, is somewhat higher in our study, especially in May when WE formed 46-52\% of DW in comparison to the 14-19\% observed in the Bothnian Bay [6]. The difference could be caused by variation in body size, which varied significantly on seasonal and annual basis, as shown by our study. In adult L. macrurus, the prosome length was closely related to the total body length, whereas oil sac length varied independently on it in most months. In our samples, large individuals did not always have the largest oil sacs, although in some dates (May 20 and July 1,2014) this was the case. Therefore, the oil sac length could express the energy reserves of adult $L$. macrurus better when expressed as total WE content than if converted to concentration on DW basis.

In the northern Baltic Sea, L. macrurus predominantly feeds on calanoid copepods throughout the year [6]. In the present study, the lipids of an adult L. macrurus contained fatty acids typical of an omnivorous and carnivorous copepod, generally characterized by high relative amounts of 14:0, 16:0, and 18:1(n-9) and low levels of long-chained monounsaturates such as 20:1(n-9) [26]. Out of all fatty acids, 16:0, 18:1(n-9), 18:2(n-6), EPA and DHA were the most abundant, together accounting approximately $56-61 \%$ of all fatty acids in June-September. In large part, our findings are in line with that of Hiltunen et al. [21] who studied the fatty acid composition of $L$. macrurus in the Bothnian Sea in August. Similar to our study, Hiltunen et al. [21] reported high proportions of these fatty acids, especially EPA and DHA. Conversely, in the arctic Laptev and Kara Seas, much lower proportions of PUFAs have been reported [22, 23] and were probably caused by high reliance on diatoms [21].

The fatty acid composition of $L$. macrurus clearly differed from that of mixed plankton, further underlining the species uniqueness in the local plankton community. In May, the large lipid reserves of adult $L$. macrurus were evidently a result of good feeding conditions, provided by the observed phytoplankton spring bloom in the surface water layer. In the Bothnian Sea, like generally in the northern Baltic, diatoms and dinoflagellates are the major component of the phytoplankton community in spring [41] and hence were expected to be the origin of lipids in L. macrurus in May, too. In May, mixed plankton contained elevated proportions of phytoplankton and diatoms markers 14:0, 16:1(n-7) and EPA [26, 42, 43] and the prevalence of these fatty acids as markers was supported by the abundant occurrence of these groups in the sample analysed. In May, L. macrurus also contained high concentrations of EPA, which together with 16:1(n7) suggests diatom uptake. However, the concentration of $16: 1(\mathrm{n}-7)$ in L. macrurus at this date was uncertain, because the analysis was disturbed by saturated hydrocarbons whose quantity could not be determined and origin can only be speculated. In marine ecosystems, hydrocarbons of varying chain lengths are produced by different micro-organisms such as cyanobacteria and diatoms $[44,45]$ and their abundant presence in the mixed plankton in May suggests that hydrocarbons were transported to L. macrurus from the environment with phytoplankton food. Alternatively, these hydrocarbons could be biosynthetic products of $L$. macrurus itself as fatty acid-hydrocarbon compounds are known to act as pheromones for instance in insects [46] and in crustaceans, pheromones have been found on the surface of the carapax, to be transmitted through physical contact [e.g., 47]. 
Chemoreception plays an important role in the behaviour copepods [48, 49]. Therefore, for L. macrurus, which spends most of its adult life in deep water where visibility is poor, these chemical substances could act as a principal method for signalling between individuals and for detection of food particles and, hence, be found in its lipids.

In comparison to May, the fatty acid composition of $L$. macrurus in June-September suggested that the species was opportunistically feeding on various types of prey. For example, the lipids of $L$. macrurus contained fatty acids 18:2(n-6) and 18:3(n-3), which, in some studies, are considered as an indication of a cyanobacteria-based diet [50]. These fatty acids were also found in the mixed plankton through the summer, which is understandable, as for instance species such as Aphanizomenon flos-aquae was relatively abundant in all of the samples. In June-September, L. macrurus also contained high proportions of diatom and dinoflagellate markers EPA and DHA [26], whose concentration also increased from June to September. A marker for carnivorous and detritivorous feeding, 18:1(n9) $[10,12]$, was also abundantly present with an increasing concentration towards September. These three fatty acids were also found in the mixed plankton samples, which included diatoms, dinoflagellates, herbivorous copepods and the ciliate $H$. subulata. Tracking definite trophic relationships from the fatty acid compositions of $L$. macrurus and mixed plankton is difficult, because the lipid signatures of L. macrurus may originate from various sources [6] and fatty acids can also be synthesized de novo by copepods [e.g., 51]. Nevertheless, the fatty acid composition can indicate trophic relationships at least at major taxonomic levels as has been shown for other omnivorous and carnivorous zooplankton species [see e.g., 26, 52, 53]. In July-September, adult $L$. macrurus were located in deeper water levels and, based on the low number of oil sacs in them, were probably unable to migrate to upper water layers, as suggested by Lindqvist [3] and Webster et al. [37]. Therefore, it is possible that in July-September L. macrurus fed on ciliates and phytoplankton, sinking from the upper water layers or, alternatively, preyed on organisms inhabiting the same water layers. A similar phenomenon was suggested by Peters et al. [39] for P. acuspes in the Central Baltic Sea.

\section{Conclusions}

In the Bothnian Sea, L. macrurus has been suggested to be a key species responsible for improving the physiological condition of herring in spring and early summer [36]. As shown by our study, the WE content of an adult $L$. macrurus is higher than that of $P$. acuspes [39], the preferred prey species of the herring in the Central Baltic Sea [40]. In spite of the apparent large energy reserves, we conclude that the summertime WE content and survival of adult L. macrurus seems to be connected to the abundant availability of good quality food. This is important in the face of the on-going climate change as climate change scenarios for the Baltic Sea predict that the plankton community will change towards smaller-sized and poor-quality taxa as a consequence of a further decline in sea water salinity and an increase of water temperature, stratification, river flow and nutrients [14]. These changes, such as a further rise in water temperature, may force $L$. macrurus to submerge permanently to deeper water where the concentration of food is low. If also the quality of food is poor, the growth of the population is most likely suppressed, causing the summer period to act as a bottleneck for population growth despite summer is the main production period of its prey organisms. However, our study does not tell about the interannual variation of the WE content in L. macrurus and no such information is found, to our knowledge, in the literature either. Therefore, interannual data on the WE content and fatty acid composition of $L$. macrurus should be collected in order to foresee these changes and to provide a more accurate picture of the trophodynamics.

\section{Abbreviations \\ ANOVA: analysis of variance; BL: body length; CB: carbon biomass; DHA: docosahexaenoic acid; 22:6(n-3); DW: dry weight; EFA: essential fatty acid; EPA: eicosapentaenoic acid; 20:5(n-3); FA: fatty acid; FAME: fatty acid methyl ester; FATM: fatty acid trophic marker concept; GC-FID: gas chromatography with flame ionization detection; GC-MS: gas chromatography-mass spectrometry; PC: principal component; PCA: principal component analysis; SVD: singular value decomposition; WE: wax ester.}

\section{Authors' contributions}

$\mathrm{KM}, \mathrm{ME}, \mathrm{MR}$ and JH contributed to data collection. LL and JS performed the lipid and fatty acid extractions and analyses. KM and MR analyzed and interpreted the data and wrote the manuscript. IV, JH and JS co-directed the research with KM and MR and participated in manuscript revisions. All authors read and approved the final manuscript.

\section{Author details}

${ }^{1}$ Archipelago Research Institute, Biodiversity Unit, University of Turku, 20014 Turku, Finland. ${ }^{2}$ Business, ICT and Chemical Engineering, Turku University of Applied Sciences, 20520 Turku, Finland. ${ }^{3}$ Food Chemistry and Food Development, Department of Biochemistry, University of Turku, 20014 Turku, Finland.

\section{Acknowledgements}

We thank the editor and two anonymous reviewers for their careful and constructive comments.

Competing interests

The authors declare that they have no competing interests.

Availability of data and materials

The datasets used and analyzed during the current study are available from the corresponding author on reasonable request.

\section{Funding}

The study was funded by Jenny and Antti Wihuri foundation.

\section{Publisher's Note}

Springer Nature remains neutral with regard to jurisdictional claims in published maps and institutional affiliations. 
Received: 9 January 2017 Accepted: 19 June 2017

Published online: 26 June 2017

\section{References}

1. Hutchinson GE. A treatise on limnology, vol. 2., Introduction to lake biology and the limnoplanktonNew York: Wiley; 1967.

2. Segerstråle SG. The distribution of glacial relicts in Finland and adjacent Russian areas. Soc Sci Fenn Comment Biol. 1956;15:1-35.

3. Lindqvist A. Studien über das Zooplankton der Bottensee I: nauplien und copepoditen von Limnocalanus grimaldii (de Guerne)(Copepoda, Calanoida). Institute of Marine Research Lysekil Ser Biol Rep No 11; 1959.

4. Lindquist A. Untersuchungen an Limnocalanus (Copepoda, Calanoida). Institute of Marine Research Lysekil Ser Biol Rep No 13; 1961.

5. Kankaala P. Structure, dynamics and production of mesozooplankton community in the Bothnian Bay, related to environmental factors. Int Rev Gesamten Hydrobiol Hydrogr. 1987. doi:10.1002/iroh.19870720202.

6. Dahlgren K, Olsen BR, Troedsson C, Bamstedt U. Seasonal variation in wax ester concentration and gut content in a Baltic Sea copepod [Limnocalanus macrurus (Sars 1863)]. J Plankton Res. 2012. doi:10.1093/plankt/ fbs005.

7. Cavaletto JF, Vanderploeg HA, Gardner WS. Wax esters in two species of freshwater zooplankton. Limnol Oceanogr. 1989. doi:10.4319/ 10.1989.34.4.0785

8. Vanderploeg HA, Cavaletto JF, Liebig JR, Gardner WS. Limnocalanus macrurus (Copepoda: Calanoida) retains a marine arctic lipid and life cycle strategy in Lake Michigan. J Plankton Res. 1998;20:1581-97.

9. Lee RF. Lipid composition of the copepod Calanus hyperboreas from the Arctic Ocean. Changes with depth and season. Mar Biol. 1974 doi:10.1007/BF00391515.

10. Lee RF, Hagen W, Kattner G. Lipid storage in marine zooplankton. Mar Ecol Prog Ser. 2006. doi:10.3354/meps307273.

11. Kattner G, Hagen W, Lee RF, et al. Perspectives on marine zooplankton lipids. Can J Fish Aquat Sci. 2007. doi:10.1139/F07-122.

12. Sargent JR, Falk-Petersen S. The lipid biochemistry of calanoid copepods. Hydrobiologia. 1988. doi:10.1007/BF00026297.

13. Schwenk D, Seppälä J, Spilling K, et al. Lipid content in 19 brackish and marine microalgae: influence of growth phase, salinity and temperature Aquat Ecol. 2013. doi:10.1007/s10452-013-9454-z.

14. HELCOM. Climate change in the Baltic Sea Area: HELCOM thematic assessment in 2013: Balt Sea Environ Proc No. 137; 2013.

15. Sandström O, Sörlin T. Production ecology in the Northern Baltic. Hydrobiologia. 1981. doi:10.1007/BF00014038.

16. Postel L, Margonski P, Lehtiniemi M, et al. Zooplankton of the Baltic Sea. In: O'brien TD, Wiebe PH, Hay S (eds) ICES Zooplankton status report 2008/2009. ICES Coop Res Rep No 307; 2011. P. 58-81.

17. Andersson A, Meier HEM, Ripszam M, et al. Projected future climate change and Baltic Sea ecosystem management. Ambio. 2015. doi:10.1007/s13280-015-0654-8.

18. Vuorinen I, Hänninen J, Rajasilta M, et al. Scenario simulations of future salinity and ecological consequences in the Baltic Sea and adjacent North Sea areas-implications for environmental monitoring. Ecol Indic. 2015. doi:10.1016/j.ecolind.2014.10.019.

19. Goulden CE, Hornig LL. Population oscillations and energy reserves in planktonic cladocera and their consequences to competition. Proc Natl Acad Sci USA. 1980;77:1716-20.

20. Holm NP, Shapiro J. An estimation of lipid reserves and the nutritional status of Daphnia pulex fed Aphanizomneon flos-aquae. Limnol Oceanogr. 1984;29:1137-40

21. Hiltunen M, Strandberg U, Keinänen M, et al. Distinctive lipid composition of the copepod Limnocalanus macrurus with a high abundance of polyunsaturated fatty acids. Lipids. 2014. doi:10.1007/s11745-014-3933-4.

22. Hirche HJ, Fetzer I, Graeve M. Limnocalanus macrurus in the Kara Sea (Arctic Ocean): an opportunistic copepod as evident from distribution and lipid patterns. Polar Biol. 2003. doi:10.1007/s00300-003-0541-9.

23. Peters J, Tuschling K, Brandt A. Zooplankton in the arctic Laptev Seafeeding ecology as indicated by fatty acid composition. J Plankton Res. 2004; $26: 227-34$
24. Leppäranta M, Myrberg K. Physical Oceanography of the Baltic Sea. Berlin: Springer; 2009

25. Kuparinen J, Leonardsson K, Mattila J, Wikner J. Food web structure and function in the Gulf of Bothnia, the Baltic Sea. Ambio. 1996;8:13-21.

26. Dalsgaard J, St John M, Kattner G, et al. Fatty acid trophic markers in the pelagic marine environment. Adv Mar Biol. 2003. doi:10.1016/ S0065-2881(03)46005-7.

27. Kankaala P, Johansson S. The influence of individual variation on length biomass regressions in 3 crustacean zooplankton species. J Plankton Res. 1986;8:1027-38.

28. Omori M, Ikeda T. Methods in zooplankton ecology. New York: Wiley; 1984.

29. Folch J, Lees M, Stanley GHS. A Simple method for the isolation and purification of total lipides from animal tissues. J Biol Chem. 1957;226:497-509.

30. Morrison WR, Smith LM. Preparation of fatty acid methyl esters and dimethylacetals from lipids with boron fluoride-methanol. J Lipid Res. 1964:5:600-8

31. Ågren JJ, Julkunen A, Penttilä I. Rapid separation of serum lipids for fatty acid analysis by a single aminopropyl column. J Lipid Res. 1992;33:1871-6.

32. R Development Core Team. R: a language and environment for statistical computing. In: R language and environment for statistical computing. R Foundation for Statistical Computing, Vienna, Austria; 2015. http:// www.R-project.org. Accessed 15 Oct 2016.

33. Oksanen J, Blanchett FG, Kindt R, Legendre P, Minchin PR, O'Hara RB et al. Vegan: community ecology package. R Package 2.0. 3. CRAN. R-project. org/package=vegan; 2012

34. Legendre P, Legendre L. Numerical ecology. 3 edn. Developments in environmental modelling 20. Amsterdam: Elsevier; 2012.

35. Roff JC. Aspects of the reproductive biology of the planktonic copepod Limnocalanus macrurus Sars, 1863. Crustaceana. 1972;22:155-60.

36. Rajasilta $M$, Hänninen J, Vuorinen I. Decreasing salinity improves the feeding conditions of the Baltic herring (Clupea harengus membras) during spring in the Bothnian Sea, northern Baltic. ICES J Mar Sci J Cons. 2014. doi:10.1093/icesjms/fsu047.

37. Webster CN, Hansson S, Didrikas T, Gorokhova E, Peltonen H, Brierley AS Lehtiniemi M. Stuck between a rock and a hard place: zooplankton vertical distribution and hypoxia in the Gulf of Finland, Baltic Sea. Mar Biol. 2015. doi:10.1007/s00227-015-2679-8.

38. Schulz J, Peck MA, Barz K, Schmidt JO, Hansen FC, Peters J, Renz J, Dickmann M, Mohrholz V, Dutz J, Hirche H-J. Spatial and temporal habitat partitioning by zooplankton in the Bornholm Basin (central Baltic Sea). Progr Oceanogr. 2012. doi:10.1016/j.pocean.2012.07.002.

39. Peters J, Renz J, van Beusekom J, et al. Trophodynamics and seasonal cycle of the copepod Pseudocalanus acuspes in the Central Baltic Sea (Bornholm Basin): evidence from lipid composition. Mar Biol. 2006. doi:10.1007/s00227-006-0290-8.

40. Möllmann C, Kornilovs G, Fetter M, Köster FW. Climate, zooplankton, and pelagic fish growth in the central Baltic Sea. ICES J Mar Sci J Cons. 2005 doi:10.1016/j.icesjms.2005.04.021.

41. Klais R, Tamminen T, Kremp A, et al. Decadal-scale changes of dinoflagellates and diatoms in the anomalous Baltic Sea spring bloom. PLoS ONE. 2011. doi:10.1371/journal.pone.0021567.

42. Dunstan GA, Volkman JK, Barrett SM, Leroi JN, Jeffrey SW. Essentia polyunsaturated fatty acids from 14 species of diatom (Bacillariophyceae). Phytochemistry. 1993. doi:10.1016/S0031-9422(00)90525-9.

43. Graeve M. Turnover and distribution of lipids in Arctic marine organisms with regard to lower trophic levels. Dissertation, University of Bremen; 1993.

44. Lee RF, Loeblich AR. Distribution of 21:6 hydrocarbon and its relationship to $22: 6$ fatty acid in algae. Phytochemistry. 1971;10:593-602.

45. Lea-Smith DJ, Biller SJ, Davey MP, Cotton CAR, Perez Sepulveda BM, Turchyn AV, Scanlan DJ, Smith AG, Chisholm SW, Howe CJ. Contribution of cyanobacterial alkane production to the ocean hydrocarbon cycle. Proc Natl Acad Sci. 2015. doi:10.1073/pnas.1507274112.

46. Pennanec'h M, Bricard L, Kunesch G, Jallon J-M. Incorporation of fatty acids into cuticular hydrocarbons of male and female Drosophila melanogaster. J Insect Physiol. 1997; 43: 1111-1116. 
47. Caskey JL, Bauer RT. Behavioral tests for a possible contact sex pheromone in the caridean shrimp Palaemonetes pugio. J Crustacean Biol. 2005:25:571-6.

48. Jiang HS, Osborn TR. Hydrodynamics of copepods: a review. Surv Geophys. 2004;25:339-70. doi:10.1007/s10712-003-1282-6.

49. Seuront L, Stanley HE. Anomalous diffusion and multifractality enhance mating encounters in the ocean. Proc Nat Acad Sci. 2014;11:2206-11.

50. Desvilettes $\mathrm{CH}$, Bourdier $\mathrm{G}$, Amblard CH, Barth B. Use of fatty acids for the assessment of zooplankton grazing on bacteria, protozoans and microalgae. Freshw Biol. 1997;38:629-37. doi:10.1046/j.1365-2427.1997.00241.x.
51. Sargent JR, Henderson RJ. Lipids. In: Corner EDS, O'Hara SCM, editors. The biological chemistry of marine copepods. Oxford: Clarendon Press; 1986. p. 59-108.

52. Graeve M, Hagen W, Kattner G. Herbivorous or omnivorous? On the significance of lipid compositions as trophic markers in Antarctic copepods. Deep-Sea Res. 1994;41:15-924.

53. Kattner G, Graeve M, Hagen W. Ontogenetic and seasonal changes in lipid and fatty acid/alcohol compositions of the dominant Antarctic copepods Calanus propinquus, Calanoides acutus and Rhincalanus gigas. Mar Biol. 1994;118:637-44.

\section{Submit your next manuscript to BioMed Central and we will help you at every step:}

- We accept pre-submission inquiries

- Our selector tool helps you to find the most relevant journal

- We provide round the clock customer support

- Convenient online submission

- Thorough peer review

- Inclusion in PubMed and all major indexing services

- Maximum visibility for your research

Submit your manuscript at www.biomedcentral.com/submit 